\title{
Effect of Tillage and Nitrogen Scheduling on Nutrients Uptake and Economics of Wheat (Triticum aestivum L.) in Central Punjab
}

\author{
Navdeep Kaur ${ }^{*}$, Iqbal Singh and Santosh Kumar \\ Department of Agriculture, Mata Gujri College, Sri Fatehgarh Sahib, Punjab, India \\ *Corresponding author
}

\section{A B S T R A C T}

\begin{tabular}{|l|}
\hline Ke y w o r d s \\
$\begin{array}{l}\text { Zero tillage, } \\
\text { Nutrients uptake, } \\
\text { Organic residue, } \\
\text { Conventional } \\
\text { tillage, Nitrogen } \\
\text { scheduling }\end{array}$ \\
\hline Article Info \\
\hline $\begin{array}{l}\text { Accepted: } \\
\text { 20 July 2020 } \\
\text { Available Online: } \\
\text { 10 August } 2020\end{array}$ \\
\hline \hline
\end{tabular}

The present research entitled, "Effect of tillage and nitrogen scheduling on yield, nutrients uptake and economics of wheat (Triticum aestivum L.) in central Punjab" was carried out at Experimental Research Farm of the Department of Agriculture, Mata Gujri College, Sri Fatehgarh Sahib, Punjab during Rabi season of 2016-2017. The soil was alluvial having sandy loam texture with $\mathrm{pH}$ 7.3. The study was done in randomized block design with twelve treatments and three replications with HD 3086 wheat variety. The aim of this study was to evaluate the impact of two tillage systems used viz., zero tillage (ZT) and conventional tillage (CT) and three nitrogen application rated $(100,125$ and $150 \mathrm{~kg} / \mathrm{ha})$ on yield components, nutrients uptake by grain and straw and economics of individual plant parameters were recorded from randomly selected plants in each plot. On the basis of results summarized, the application of $\mathrm{T}_{11}-\mathrm{ZT}+\mathrm{N}_{5}$ i.e. $\mathrm{N} @ 125 \mathrm{~kg}$ (4 splits) applied at 1/4, $1 / 4,1 / 4$ and $1 / 4$ at basal, 4, 6 and 8 WAS gave the best result in terms of crop yield, nutrients uptake by grain and straw and economics which is statistically at par to the application of $\mathrm{T}_{5}-\mathrm{CT}+\mathrm{N}_{5}$ i.e. $\mathrm{N} @ 125 \mathrm{~kg}$ (4 splits) applied at $1 / 4,1 / 4,1 / 4$ and $1 / 4$ at basal, 4, 6 and 8 WAS and $\mathrm{T}_{12}-\mathrm{ZT}+\mathrm{N}_{6}$ i.e. $\mathrm{N} @ 150 \mathrm{~kg}$ (4 splits) applied at 1/4, 1/4, 1/4 and 1/4 at basal, 4, 6 and 8 WAS.

\section{Introduction}

Wheat (Triticum aestivum L.) is the second most important cereal crop in India with an average area of 29.7 mha and annual production of $92.5 \mathrm{mt}$ which contribute approximately $12.5 \%$ and $12 \%$ in world's wheat area and production respectively. In India, Uttar Pradesh stands first in respect of area followed by Madhya Pradesh, Punjab. In production, Uttar Pradesh also stands first followed by Punjab, Haryana, Madhya Pradesh. As regards to the productivity,
Punjab stands first with $4531 \mathrm{~kg} / \mathrm{ha}$ followed by Haryana with $4066 \mathrm{~kg} / \mathrm{ha}$ (Anonymous 2014-2015). The production of wheat can be improved and enhanced by using better inputs, proper production technology and appropriate tillage methods. Tillage and nitrogen can be considered as the most critical management practices as both affect the production potential of wheat. Soil tillage is one of the fundamental agro-technical operations in agriculture because of its influence on soil properties, environment and crop yield. Tillage plays important role in 
changing initial state of soil which modify whole environment likes bulk density and porosity which affects the infiltration rate of soil. Bhattachariya et al., 2008 reported that change in bulk density depends on the intensity of tillage systems. Different tillage systems produce different results like zero tillage (ZT) promotes soil organic carbon (SOC) sequestration, improves soil aggregates and better pore size allocation while conventional tillage (CT) usually increases available water capacity and infiltration rate and decreases run-off. The continuous adoption of conventional tillage makes the soil more compact and a hardpan is usually developed underneath the plough layer with high bulk density and lower saturated hydraulic conductivity which hinder the movement of water and air, inhibits root growth and reduces crop yield (Huang et al., 2012). Moreover, low precipitation ( $<200 \mathrm{~mm}$ annually) and highly pulverized surface soils caused by repeated tillage increases the wind erosion, energy usage and soil degradation. In order to minimize the degradation of the physical and chemical properties of the soil and increases water availability for crops, conservation tillage could be a key measures. The conservation tillage embraces crop production system involving management of surface residues.

The conservation tillage is helpful in maintaining soil moisture in comparison to intensive tillage operations (Hatfield and Stewart, 1994). Zero tillage improves water and nutrient use efficiencies and increase crop productivity and carbon sequestration, ameliorate soil properties and mitigate green house gasses emission. Zero tillage exhibited highest grain yield (4.8 t/ha) of wheat after rice as compared to conventional till (4.5 t/ha), deep tillage (4.4 t/ha) and reduced tillage (4.3 t/ha) (Imran et al., 2013). Sen et al., 2002 reported significantly higher yield of wheat under zero tillage than under conventional tillage.
Nitrogen is the most essential fertilizer element playing vital role in yield improvement of wheat. Nitrogen often affects amino acid composition of protein and in turns its nutritional quality (Joshi et al., 2014). The application of nitrogen fertilizers increases nitrogen content of leaves in addition to chlorophyll and carotenoids as a consequence leaf and photosynthesis is increased and thus increases dry matter production. Nitrogen is frequently reported as deficient in agricultural soils of India (Islam, 1990). Intensive farming system of high yielding varieties (HYV) of cereal crops and the removal of crop residue including the roots causing considerable decline in both organic matter and nitrogen content in agricultural soils of India.

Nitrogen deficiency generally results in stunted growth and chlorotic leaves caused by poor assimilate formation that leads to premature flowering and shortening of the growth cycle while the presence of nitrogen in excess promotes development of above ground organs with abundant dark green (high chlorophyll-II) tissues of soft consistency and relatively poor root growth. This enhances the risk of lodging and reduces the plants resistance to brash climatic condition and foliar diseases (Mohammadin et al., 2011). Nitrogen use and demand is continuously increasing day by day (Abd El-Lattief, 2011). Since it is highly mobile, it is subjected to greater losses from the soil-plant system. Even under the best management practices, $30-50 \%$ of applied nitrogen is lost through different agencies and hence the farmers compelled to apply more than the actual need of crop to compensate the losses. The loss of nitrogen not only troubles the farmers but it has also hazardous impacts on the environment. Many strategies have been developed to mitigate nutrients leaching and improve the nutrients use efficiency (NUE). The timing of fertilizer application is one of 
the low cost strategy to reduce nutrient leaching so that the nutrients supply is synchronized with plant demand (Gehl et al., 2005). The split application of nitrogen reported as beneficial rather than basal application of all nitrogenous fertilizers. The split application of nitrogen is one of the methods to improve nitrogen use by the crop while reducing the nutrients loss through leaching and volatilization (Tadesse et al., 2013). Mishra et al., 2006 showed that split application of nitrogenous fertilizer to 4 doses i.e. first at sowing, second at crown root initiation stage, third at tillering and fourth at jointing stage was found superior than other nitrogen scheduling treatments in terms of increased wheat yield and nitrogen use efficiency. Usman et al., 2012 found that the highest grain yield and number of spikes/m of wheat was obtained with the application of $\mathrm{N} @ 200 \mathrm{~kg} / \mathrm{ha}$ applied in three splits and zero tillage. The two-third of nitrogen fertilizer applied as basal during final land preparation and rest one-third applied as top dressing at crown root initiation (CRI) stage reported as most efficient in improving grain yield of wheat (Singh et al., 2013).

\section{Materials and Methods}

\section{Experimental site}

The experiment was conducted at the student's research farm of Mata Gujri College, Sri Fatehgarh Sahib during Rabi season of year 2016-2017. The experimental site falls in the sub-tropical plains of Punjab at the elevation of 247 meters above the mean sea level. The site represents $30^{\circ}-27^{\circ}$ and $30^{\circ}-46^{\circ} \mathrm{N}$ latitude and $76^{\circ}-04^{0}$ and $76^{\circ}-$ $38^{0}$ E longitude.

\section{Experimental design and treatments}

The experiment was laid out in randomized block design with twelve treatments and three replications. The whole plot was divided into 36 sub-plots and dimension of each plot was $4.0 \mathrm{~m} \mathrm{X} 3.0 \mathrm{~m}$.

\section{Crop management}

The experimental field was thoroughly ploughed with the help of tractors and followed by planking two days prior to actual date of sowing. The stones and pebbles were removed from the field. The sowing of wheat variety "HD 3086" was sown in the experimental field on $25^{\text {th }}$ November 2016. The wheat crop was sown using seed rate 100 $\mathrm{kg} / \mathrm{ha}$ at row to row spacing of $22.5 \mathrm{~cm}$ by zero tillage. The seed was placed at about 4-5 cm deep.

The organic manures such as Farm Yard Manure (FYM) @ 5-6 t/ha was applied on dry weight basis three weeks prior to sowing and thoroughly mixed with soil in the field. The recommended dose of fertilizer of $\mathrm{P}$ and $\mathrm{K}$ for wheat is 52 and $30 \mathrm{~kg} /$ ha respectively applied at the time of sowing. The amount of nitrogen was applied at per treatment wise. Nitrogen, phosphorus and potassium were applied through urea, diammonium phosphate and murate of potash respectively.

\section{Soil sampling and statistical analysis}

The undisturbed soil cores $(15 \mathrm{~cm}$ high and 6$7 \mathrm{~cm}$ diameter) were obtained from $0-15 \mathrm{~cm}$ soil depths from each plot. Soil parameters such as soil $\mathrm{pH}$, organic carbon, electrical conductivity, available nitrogen, phosphorus and potassium were determined.

The grain yield of each plot was recorded and converted in hectares. The statistical analysis was done as per the procedures given by Gomez and Gomez (1984). The interpretation of results is based on ' $F$ ' test. The critical difference (CD) was worked out for significant treatments. 


\section{Results and Discussion}

\section{Effect on crop yield}

The result of the present study indicated that the yield is the result of co-ordinate interplay of various growth characters. Grain yield $(\mathrm{q} / \mathrm{ha})$, Straw yield $(\mathrm{q} / \mathrm{ha})$, Biological yield (q/ha) and Harvest index (\%) were significantly influenced by different treatments. The application of $\mathrm{T}_{11}-\mathrm{ZT}+\mathrm{N}_{5}$ i.e. N@125 kg (4 splits) applied at 1/4, 1/4,1/4 and $1 / 4$ at basal, 4, 6 and 8 WAS recorded higher grain yield which was at par with $\mathrm{T}_{5}$ $\mathrm{CT}+\mathrm{N}_{5}$ i.e. $\mathrm{N} @ 125 \mathrm{~kg}$ (4 splits) applied at $1 / 4,1 / 4,1 / 4$ and $1 / 4$ at basal, 4,6 and 8 WAS \& $\mathrm{T}_{12}-\mathrm{ZT}+\mathrm{N}_{6}$ i.e. N@150 kg (4 splits) applied at $1 / 4,1 / 4,1 / 4$ and $1 / 4$ at basal, 4,6 and 8 WAS and it recorded significantly superior over rest of treatments. However in case of biological yield, the highest value was recorded with the application of ZT $+\mathrm{N}_{5}$ i.e. $\mathrm{N} @ 125 \mathrm{~kg}$ (4 splits) applied at $1 / 4,1 / 4,1 / 4$ and $1 / 4$ at basal, 4,6 and 8 WAS and found at par with $\mathrm{T}_{5}-\mathrm{CT}+$ $\mathrm{N}_{5}$ i.e. N@125 kg (4 splits) applied at 1/4, 1/4, $1 / 4$ and $1 / 4$ at basal, 4, 6 and 8 WAS which was significantly superior over rest of treatments. This result was attributed due to adequate availability of nutrient thus marked improvement in dry matter accumulation and better nutrient uptake. The treatments which had higher growth attributing characters produced higher crop yield. Further seed and yield of wheat enhanced significantly at higher levels of NPK and integrated with organic residue and inorganic fertilizers. Application of organic residue increased grain and straw yield of wheat. The highest yields were recorded under the treatment of integration of NPK with crop residue. There was positive correlation between grain yield and yield components like number of effective tillers and grain spike which were increased in nutrient availability and high nutrient uptake due to higher nutrient availability to crop. Similar results were reported by Fisher et al., (2003), Kumar et al., (2005) and Subedy et al., (2007).

\section{Effect on nutrient uptake by crop plants}

The maximum uptake of $\mathrm{N}_{2} \mathrm{P}_{2} \mathrm{O}_{5}$ and $\mathrm{K}_{2} \mathrm{O}$ by crop with the application of $\mathrm{T}_{11}-\mathrm{ZT}+\mathrm{N}_{5}$ i.e. $\mathrm{N} @ 125 \mathrm{~kg}$ (4 splits) applied at $1 / 4,1 / 4,1 / 4$ and $1 / 4$ at basal, 4, 6 and 8 WAS which was followed by of $\mathrm{T}_{5}-\mathrm{CT}+\mathrm{N}_{5}$ i.e. $\mathrm{N} @ 125 \mathrm{~kg}$ (4 splits) applied at $1 / 4,1 / 4,1 / 4$ and $1 / 4$ at basal, 4,6 and 8 WAS which was found significantly superior over rest of the treatments. But the minimum uptake of $\mathrm{N}, \mathrm{P}$ and $\mathrm{K}$ was in $\mathrm{T}_{1}$ - control treatments. Interaction of tillage and nitrogen schedule on crop also was significant on $\mathrm{N} \mathrm{P}$ K uptake by plant (Table 1-7).

Table.1 Initial fertility of soil

\begin{tabular}{|c|c|c|}
\hline Particular & $\begin{array}{c}\text { Value } \\
\text { obtained }\end{array}$ & Method employed \\
\hline Texture & Sandy loam & International pipette method (Piper, 1966) \\
\hline Soil pH & 7.3 & $\begin{array}{l}\text { 1: } 2 \text { soil: water suspensions with the help of digital } \mathrm{pH} \text { meter } \\
\text { (Jackson, 1973) }\end{array}$ \\
\hline Soil Organic & 0.42 & Walkey and Black method (1934) \\
\hline Soil EC $\left(\mathrm{dSm}^{-1}\right)$ & 0.50 & With the help of digital conductivity meter. \\
\hline Available N (kg/ha) & 215.5 & $\begin{array}{l}\text { Alkaline potassium permanganate method of Subbiah and Asija } \\
\text { (1956) }\end{array}$ \\
\hline Available $\mathrm{P}_{2} \mathrm{C}$ & & Olsen et al., (1954) \\
\hline Available $\mathrm{K}_{2} \mathrm{O}(\mathrm{kg} / \mathrm{ha})$ & 122.30 & Ammonium acetate method of Merwin and Peech (1951) \\
\hline
\end{tabular}


Table.2 Experimental detail

\begin{tabular}{|l|l|}
\hline Variety & HD 3086 \\
\hline Date of Sowing & Timely sown (Rabi season) \\
\hline Number of treatments & 12 \\
\hline Number of replication & 3 \\
\hline Total number of treatments & 36 \\
\hline Design & Randomized Block Design \\
\hline Replication border & $1.0 \mathrm{~m}$ \\
\hline Gross plot size & $4.0 \mathrm{~m} \mathrm{x} \mathrm{3.0} \mathrm{m}$ \\
\hline Net plot size & $3.77 \mathrm{~m} \mathrm{x} 2.77 \mathrm{~m}$ \\
\hline Spacing row to row & $22.5 \mathrm{~cm}$ \\
\hline
\end{tabular}

Table.3 Detail of treatments

\begin{tabular}{|c|c|}
\hline Treatments & Treatment Combination \\
\hline $\mathbf{T}_{1}$ & $\mathrm{CT}+\mathrm{N}_{1}$ i.e. Control \\
\hline $\mathbf{T}_{2}$ & $\mathrm{CT}+\mathrm{N}_{2}$ i.e. $\mathrm{N} @ 100 \mathrm{~kg}$ ( 2 splits) applied $1 / 2$ at basal and $1 / 2$ at $4 \mathrm{WAS}$ \\
\hline $\mathbf{T}_{3}$ & $\mathrm{CT}+\mathrm{N}_{3}$ i.e. $\mathrm{N} @ 100 \mathrm{~kg}$ (3 splits) applied $1 / 2$ at basal, $1 / 4$ at $4 \mathrm{WAS}$ and $1 / 4$ at $8 \mathrm{WAS}$ \\
\hline $\mathbf{T}_{4}$ & $\mathrm{CT}+\mathrm{N}_{4}$ i.e. N@125 kg (2 splits) applied 1/2 at basal and 1/2 at 4 WAS \\
\hline $\mathbf{T}_{5}$ & $\mathrm{CT}+\mathrm{N}_{5}$ i.e. $\mathrm{N} @ 125 \mathrm{~kg}$ (4 splits) applied at $1 / 4,1 / 4,1 / 4$ and $1 / 4$ at basal, 4,6 and 8 WAS \\
\hline $\mathbf{T}_{6}$ & $\mathrm{CT}+\mathrm{N}_{6}$ i.e. $\mathrm{N} @ 150 \mathrm{~kg}$ (4 splits) applied at $1 / 4,1 / 4,1 / 4$ and $1 / 4$ at basal, 4,6 and 8 WAS \\
\hline $\mathbf{T}_{7}$ & $\mathrm{ZT}+\mathrm{N}_{1}$ i.e. Control \\
\hline $\mathbf{T}_{8}$ & $\mathrm{ZT}+\mathrm{N}_{2}$ i.e. $\mathrm{N} @ 100 \mathrm{~kg}$ ( 2 splits) applied $1 / 2$ at basal and $1 / 2$ at $4 \mathrm{WAS}$ \\
\hline $\mathbf{T}_{9}$ & $\mathrm{ZT}+\mathrm{N}_{3}$ i.e. $\mathrm{N} @ 100 \mathrm{~kg}(3$ splits $)$ applied $1 / 2$ at basal, $1 / 4$ at $4 \mathrm{WAS}$ and $1 / 4$ at 8 WAS \\
\hline $\mathbf{T}_{10}$ & $\mathrm{ZT}+\mathrm{N}_{4}$ i.e. $\mathrm{N} @ 125 \mathrm{~kg}(2$ splits $)$ applied $1 / 2$ at basal and $1 / 2$ at 4 WAS \\
\hline $\mathbf{T}_{11}$ & $\mathrm{ZT}+\mathrm{N}_{5}$ i.e. $\mathrm{N} @ 125 \mathrm{~kg}$ (4 splits) applied at $1 / 4,1 / 4,1 / 4$ and $1 / 4$ at basal, 4,6 and 8 WAS \\
\hline $\mathbf{T}_{12}$ & $\mathrm{ZT}+\mathrm{N}_{6}$ i.e. N@150 kg (4 splits) applied at 1/4,1/4,1/4 and $1 / 4$ at basal, 4, 6 and 8 WAS \\
\hline
\end{tabular}

CT- Conventional Tillage and ZT- Zero Tillage

Table.4 Effect of tillage and nitrogen scheduling on crop yield (q/ha) and harvest Index (\%)

\begin{tabular}{|c|c|c|c|c|}
\hline Treatment & Grain Yield (q/ha) & Straw Yield (q/ha) & Biological Yield (q/ha) & Harvest Index (\%) \\
\hline $\mathbf{T}_{1}-\mathbf{C T}+\mathbf{N}_{1}$ & 28.27 & 52.34 & 80.61 & 35.07 \\
\hline $\mathrm{T}_{2}-\mathrm{CT}+\mathrm{N}_{2}$ & 34.55 & 55.09 & 89.94 & 38.54 \\
\hline $\mathbf{T}_{3}-\mathbf{C T}+\mathbf{N}_{3}$ & 40.46 & 58.94 & 99.40 & 40.70 \\
\hline $\mathbf{T}_{4}-\mathrm{CT}+\mathrm{N}_{4}$ & 43.71 & 59.45 & 103.16 & 42.37 \\
\hline $\mathbf{T}_{5}-\mathbf{C T}+\mathbf{N}_{5}$ & 51.92 & 64.81 & 116.73 & 44.47 \\
\hline $\mathrm{T}_{6}-\mathrm{CT}+\mathrm{N}_{6}$ & 46.38 & 62.63 & 109.01 & 42.54 \\
\hline $\mathbf{T}_{7}-\mathbf{Z T}+\mathbf{N}_{1}$ & 30.04 & 53.57 & 83.61 & 35.92 \\
\hline $\mathrm{T}_{8}-\mathrm{ZT}+\mathrm{N}_{2}$ & 35.59 & 56.18 & 91.77 & 38.78 \\
\hline $\mathbf{T}_{9}-\mathrm{ZT}+\mathrm{N}_{3}$ & 42.13 & 59.21 & 101.34 & 41.57 \\
\hline $\mathbf{T}_{10}-\mathrm{ZT}+\mathrm{N}_{4}$ & 44.51 & 61.93 & 106.44 & 41.81 \\
\hline$T_{11}-Z T+N_{5}$ & 52.96 & 66.09 & 119.05 & 44.49 \\
\hline $\mathbf{T}_{12}-\mathrm{ZT}+\mathrm{N}_{6}$ & 49.60 & 63.72 & 113.32 & 43.76 \\
\hline SEm \pm & 1.32 & 1.35 & 1.36 & 1.40 \\
\hline CD at $5 \%$ & 3.87 & 3.96 & 4.00 & 4.10 \\
\hline
\end{tabular}


Table.5 Effect of tillage and nitrogen scheduling on nutrient content (\%) in grain and straw

\begin{tabular}{|c|c|c|c|c|c|c|}
\hline \multirow[t]{2}{*}{ Treatments } & \multicolumn{3}{|c|}{ Grain } & \multicolumn{3}{|c|}{ Straw } \\
\hline & $\mathbf{N}$ & $\mathbf{P}$ & $\mathbf{K}$ & $\mathbf{N}$ & $\mathbf{P}$ & $\mathbf{K}$ \\
\hline $\mathrm{T}_{1}-\mathrm{CT}+\mathrm{N}_{1}$ & 1.54 & 0.24 & 0.17 & 0.76 & 0.04 & 1.29 \\
\hline $\mathbf{T}_{2}-\mathrm{CT}+\mathrm{N}_{2}$ & 1.59 & 0.29 & 0.22 & 0.79 & 0.05 & 1.34 \\
\hline $\mathrm{T}_{3}-\mathrm{CT}+\mathrm{N}_{3}$ & 1.66 & 0.34 & 0.28 & 0.84 & 0.06 & 1.39 \\
\hline $\mathbf{T}_{4}-\mathrm{CT}+\mathrm{N}_{4}$ & 1.73 & 0.39 & 0.31 & 0.88 & 0.08 & 1.44 \\
\hline $\mathbf{T}_{5}-\mathbf{C T}+\mathbf{N}_{5}$ & 1.86 & 0.47 & 0.41 & 0.95 & 0.10 & 1.54 \\
\hline$T_{6}-C T+N_{6}$ & 1.81 & 0.42 & 0.35 & 0.92 & 0.09 & 1.49 \\
\hline $\mathbf{T}_{7}-\mathbf{Z T}+\mathbf{N}_{\mathbf{1}}$ & 1.57 & 0.26 & 0.20 & 0.78 & 0.04 & 1.32 \\
\hline $\mathrm{T}_{8}-\mathrm{ZT}+\mathrm{N}_{2}$ & 1.62 & 0.31 & 0.26 & 0.81 & 0.06 & 1.37 \\
\hline$T_{9}-Z T+N_{3}$ & 1.70 & 0.36 & 0.30 & 0.85 & 0.07 & 1.42 \\
\hline $\mathrm{T}_{10}-\mathrm{ZT}+\mathrm{N}_{4}$ & 1.77 & 0.40 & 0.33 & 0.90 & 0.08 & 1.47 \\
\hline $\mathrm{T}_{11}-\mathrm{ZT}+\mathrm{N}_{5}$ & 1.89 & 0.48 & 0.44 & 0.97 & 0.11 & 1.57 \\
\hline$T_{12^{-}} Z \mathrm{ZT}+\mathrm{N}_{6}$ & 1.79 & 0.45 & 0.39 & 0.93 & 0.10 & 1.52 \\
\hline SEm \pm & 0.02 & 0.01 & 0.01 & 0.01 & 0.01 & 0.01 \\
\hline CD at $5 \%$ & NS & NS & NS & NS & NS & NS \\
\hline
\end{tabular}

Table.6 Effect of tillage and nitrogen scheduling on nutrient uptake $(\mathrm{kg} / \mathrm{ha})$ in grain and straw

\begin{tabular}{|c|c|c|c|c|c|c|c|c|c|}
\hline \multirow[t]{2}{*}{ Treatments } & \multicolumn{3}{|c|}{ Grain } & \multicolumn{3}{|c|}{ Straw } & \multicolumn{3}{|c|}{ Crop } \\
\hline & $\mathbf{N}$ & $\mathbf{P}$ & $\mathbf{K}$ & $\mathbf{N}$ & $\mathbf{P}$ & $\mathbf{K}$ & $\mathbf{N}$ & $\mathbf{P}$ & $\mathbf{K}$ \\
\hline $\mathrm{T}_{1}-\mathrm{CT}+\mathrm{N}_{1}$ & 43.54 & 6.79 & 4.81 & 39.78 & 2.10 & 67.52 & 83.32 & 8.89 & 72.33 \\
\hline $\mathrm{T}_{2}-\mathrm{CT}+\mathrm{N}_{2}$ & 54.93 & 10.02 & 7.60 & 43.52 & 2.75 & 73.83 & 98.45 & 12.77 & 81.43 \\
\hline $\mathrm{T}_{3}-\mathrm{CT}+\mathrm{N}_{3}$ & 67.17 & 13.76 & 11.33 & 49.51 & 3.54 & 81.93 & 116.68 & 17.30 & 93.26 \\
\hline $\mathrm{T}_{4}-\mathrm{CT}+\mathrm{N}_{4}$ & 75.62 & 17.05 & 13.56 & 52.32 & 4.76 & 85.61 & 127.94 & 21.81 & 99.17 \\
\hline $\mathrm{T}_{5}-\mathrm{CT}+\mathrm{N}_{5}$ & 96.58 & 24.41 & 21.29 & 61.57 & 6.49 & 99.80 & 159.48 & 30.90 & 121.88 \\
\hline $\mathrm{T}_{6}-\mathrm{CT}+\mathrm{N}_{6}$ & 83.95 & 19.48 & 16.23 & 57.62 & 5.64 & 93.32 & 141.57 & 25.12 & 109.55 \\
\hline $\mathrm{T}_{7}-\mathrm{ZT}+\mathrm{N}_{1}$ & 47.16 & 7.82 & 6.01 & 41.79 & 2.15 & 70.72 & 88.95 & 9.97 & 76.73 \\
\hline $\mathrm{T}_{8}-\mathrm{ZT}+\mathrm{N}_{2}$ & 57.65 & 11.04 & 9.26 & 45.50 & 3.38 & 76.97 & 103.15 & 14.42 & 86.23 \\
\hline $\mathrm{T}_{9}-\mathrm{ZT}+\mathrm{N}_{3}$ & 71.62 & 15.17 & 12.64 & 50.33 & 4.15 & 84.08 & 121.95 & 19.32 & 96.72 \\
\hline $\mathrm{T}_{10}-\mathrm{ZT}+\mathrm{N}_{4}$ & 78.79 & 17.81 & 14.66 & 55.74 & 4.96 & 91.04 & 134.53 & 22.77 & 105.70 \\
\hline $\mathrm{T}_{11}-\mathrm{ZT}+\mathrm{N}_{5}$ & 100.10 & 25.43 & 23.31 & 64.11 & 7.27 & 103.77 & 162.88 & 32.70 & 125.75 \\
\hline $\mathrm{T}_{12}-\mathrm{ZT}+\mathrm{N}_{6}$ & 88.79 & 22.32 & 19.35 & 59.26 & 6.38 & 96.86 & 149.38 & 28.70 & 116.21 \\
\hline SEm \pm & 1.40 & 1.11 & 0.92 & 1.34 & 0.36 & 1.37 & 1.54 & 0.80 & 1.41 \\
\hline CD at $5 \%$ & 4.12 & 3.25 & 2.71 & 3.92 & 1.07 & 4.02 & 4.52 & 2.36 & 4.13 \\
\hline
\end{tabular}


Table.7 Effect of tillage and nitrogen scheduling on economics of crop

\begin{tabular}{|c|c|c|c|c|}
\hline Treatments & $\begin{array}{c}\text { Cost of cultivation } \\
\text { (₹/ha) }\end{array}$ & $\begin{array}{c}\text { Gross return } \\
\text { (₹/ha) }\end{array}$ & Net return (₹/ha) & $\begin{array}{c}\text { B:C } \\
\text { Ratio }\end{array}$ \\
\hline $\mathbf{T}_{\mathbf{1}}-\mathbf{C T}+\mathbf{N}_{\mathbf{1}}$ & 41590.16 & 69491.75 & 27901.59 & 0.67 \\
\hline $\mathbf{T}_{\mathbf{2}}-\mathbf{C T}+\mathbf{N}_{\mathbf{2}}$ & 43790.16 & 80934.25 & 37144.09 & 0.84 \\
\hline $\mathbf{T}_{\mathbf{3}}-\mathbf{C T}+\mathbf{N}_{\mathbf{3}}$ & 45290.16 & 92270.5 & 46980.34 & 1.03 \\
\hline $\mathbf{T}_{\mathbf{4}}-\mathbf{C T}+\mathbf{N}_{\mathbf{4}}$ & 47190.16 & 97781.25 & 50591.09 & 1.07 \\
\hline $\mathbf{T}_{\mathbf{5}} \mathbf{C} \mathbf{C}+\mathbf{N}_{\mathbf{5}}$ & 51390.16 & 113534.5 & 62144.34 & 1.20 \\
\hline $\mathbf{T}_{\mathbf{6}} \mathbf{C T}+\mathbf{N}_{\mathbf{6}}$ & 49390.16 & 103551 & 54160.84 & 1.09 \\
\hline $\mathbf{T}_{\mathbf{7}} \mathbf{Z T}+\mathbf{N}_{\mathbf{1}}$ & 41590.16 & 72921.5 & 31331.34 & 0.75 \\
\hline $\mathbf{T}_{\mathbf{8}} \mathbf{Z} \mathbf{Z T}+\mathbf{N}_{\mathbf{2}}$ & 44390.16 & 83114.75 & 38724.59 & 0.87 \\
\hline $\mathbf{T}_{\mathbf{9}}-\mathbf{Z T}+\mathbf{N}_{\mathbf{3}}$ & 46090.16 & 95105.75 & 49015.59 & 1.06 \\
\hline $\mathbf{T}_{\mathbf{1 0}}-\mathbf{Z T}+\mathbf{N}_{\mathbf{4}}$ & 48190.16 & 100197.25 & 52007.09 & 1.07 \\
\hline $\mathbf{T}_{\mathbf{1 1}}-\mathbf{Z T}+\mathbf{N}_{\mathbf{5}}$ & 52290.16 & 115800.5 & 63510.34 & 1.21 \\
\hline $\mathbf{T}_{\mathbf{1 2}} \mathbf{Z} \mathbf{Z T}+\mathbf{N}_{\mathbf{6}}$ & 50490.16 & 109274 & 58783.84 & 1.16 \\
\hline
\end{tabular}

Nutrients uptake increased due to application of integration of NPK with crop residue and FYM. In this treatment, nutrient availability higher and also helps in solubilizing the nutrients. Similar results were reported by Gangwar et al., (2004), Kumar and Yadav (2005), Tripathi et al., (2010) and Kaushal et al., (2012).

\section{Effect on economics of crop}

The gross return showed considerable differences in various treatments. The highest net return and $\mathrm{B}: \mathrm{C}$ ratio was computed with the application of $\mathrm{T}_{11}-\mathrm{ZT}+\mathrm{N}_{5}$ i.e. $\mathrm{N} @ 125$ $\mathrm{kg}$ (4 splits) applied at $1 / 4,1 / 4,1 / 4$ and $1 / 4$ at basal, 4, 6 and 8 WAS which was followed by of $\mathrm{T}_{5}-\mathrm{CT}+\mathrm{N}_{5}$ i.e. $\mathrm{N} @ 125 \mathrm{~kg}$ (4 splits) applied at 1/4, 1/4, 1/4 and $1 / 4$ at basal, 4, 6 and 8 WAS. Minimum net return and B: C ratio was observed under $\mathrm{T}_{1}$ - control treatments. This was possible due to higher number of tillers grains in per spikelets, test weight ultimately higher total production of wheat which in turns increased the net returns compared to other treatments. Higher B: C was obtained in these treatments due to higher grain yield which in turn increased the net returns. These findings are closely in confirmation to the finding of Pal and Bhatnagar et al., (2008), Usman et al., (2012) and Singh et al., (2013).

In conclusion on the basis of results summarized above, it can be concluded that application of $\mathrm{T}_{11}-\mathrm{ZT}+\mathrm{N}_{5}$ i.e. $\mathrm{N} @ 125 \mathrm{~kg}$ (4 splits) applied at 1/4, 1/4, 1/4 and $1 / 4$ at basal, 4, 6 and 8 WAS gave best results of respect to all the crop yield, total nutrients uptake by grain and straw and economics of crop and second best treatment is $\mathrm{T}_{5}-\mathrm{CT}+\mathrm{N}_{5}$ i.e. $\mathrm{N} @ 125 \mathrm{~kg}$ (4 splits) applied at 1/4, 1/4, 1/4 and $1 / 4$ at basal, 4, 6 and 8 WAS. The lowest net income overall was in $\mathrm{T}_{1}-\mathrm{CT}+\mathrm{N}_{1}$ i.e. control treatment.

\section{References}

Abd El-Lattief. Nitrogen management effect on the production of two sweet sorghum cultivars under arid regions conditions. Asian Journal of Crop Science. 2011; 3(2):77-84.

Anonymous. According to Directorate of Economics and Statistics, Department of Agriculture and Cooperation. 20142015.

Bhattachariya R, Kundu S, Pandey SC, Singh 
KP, Gupta HS. Tillage and irrigation effects on crop yields and soil properties under the rice-wheat system in the Indian Himalayas. Agricultural Water Management. 2008; 95:9931002.

Fisher RA, Howe GN, Ibrahim Z. Irrigated spring wheat and timig and amount of nitrogen fertilizer on grain yield and protein content. Field Crop Research. 2003; 33:37-56.

Gangwar KS, Singh KK, Sharma SK and Tomar OK. Alternative tillage and crop residue management in wheat after rice in sandy loam soils of Indo-Gangetic Plains of India. Soil Tillage Research. 2004; 88:242-52.

Gehl RJ, Schmidt JP, Maddux LD and Gordan WB. Corn yield response to nitrogen rate and timing in sandy irrigated soils. Agronomy Journal. 2005; 97: 1230-1238.

Gomez KA, Gomez AA. Statistical procedures for agricultural research 2nd Edition. John Willey and Sons, New York. 1984, 680.

Hatfield JL and Stewart BA. Advances in Soil Sciences: Crops residue management. CRC Press, Boca Raton. 1994.

Huang M, Dang T, Gallichand J, Goulet M. Effect of increased fertilizer application to wheat crop on soil water depletion in the losses plateau, China. Agricultural Water Management. 2012; 58:267-278.

Imran A, Shafi J, Akbar N, Ahmad W, Ali M and Tariq S. Response of wheat cultivars to different tillage practices grown under rice-wheat cropping system. Universal Journal Plant Science. 2013; 1(4):125-31.

Islam MS. Nutrient status of some soils of Bangladesh. In: Proc. International symposium on paddy soil fertility. Bangladesh Agricultural research Council, Dhaka. 1990.
Jackson ML. Soil chemical analysis. Prentice Hall of India Private Limited, New Delhi. 1967.

Joshi A, Gupta JK, Choudhary SK and Paliwal DK. Efficiency of different nitrogen sources, doses and split application on growth and yield of maize in the Malwa region of Madhya Pradesh. IOSR Journal of Agriculture and Veterinary Sciences. 2014; 7(1):39-42.

Kaushal M, Singh A and Kang JS. Effect of planting techniques and nitrogen levels on growth, yield and nitrogen recovery in wheat. Journal Research Punjab Agricultural University. 2012;49:1416.

Kumar R, Yadav DS. Effect of zero tillage in conjunction with nitrogen management in wheat after rice. Indian Journal of Agronomy. 2005; 50:54-57.

Kumar, Sandeep, Pandey DS and Rana NS. Economics and yield potential of wheat as affected by tillage, rice residue and nitrogen management options under rice-wheat system. Indian Journal of Agricultural Sciences. 2005; 80(1):2932.

Mishra JS and Singh VP. Tillage and weed control effects on productivity of a dry seeded rice-wheat system on a Vertisol in Central India. Soil and Tillage Research. 2006; 123: 11-20.

Merwin HD and Peech. Exchangeability of soil potassium in the sand, silt and clay fractions as influenced by the nature of the complementary captions. Soil Science Society of America Procceedings. 1951; 15: 125-128.

Mohammadin RN, Azarpor E and Moradi M. Stady effects of different nitrogen and micronutrients fertilizers rates on yield and yield components of rice. World Applied Science Journal. 2011; 13(3):419-423.

Olsen SR. Estimation of available phosphorus 
in soils by extraction with sodium bicarnate. United States Department of Agriculture Circular No. 939. 1954; 1 9.

Pal MS and Bhatnagar A. Effect of nitrogen scheduling on productivity, profitability and nitrogen use efficiency in maize under Tarai region of Uttarakhand. International Journal of Basic and Applied Agricultural Research. 2008; 13(1): 5-9.

Piper CS. Soil and plant analysis. University of Adelaide, Australia. 1967; 286.

Sen A, Sharma SN, Singh RK and Pandey MD. Effect of different tillage systems on the performance of wheat. Proceedings of the International Workshop on Herbicide Resistance Management and Zero Tillage in RiceWheat Cropping System, CCS HAU, Hisar. 2002; 115-116.

Singh RK, Kumar P, Prasad B, Das AK, Singh SB. Effect of split application of nitrogen on performance of wheat. International Journal of Agricultural Sciences. 2013; 12(1):32-37.

Subbaiah BV and Asija GL. A rapid method for the estimation of available nitrogen in soil. Current Science. 1956; 25: 259260.

Subedy KD, Ma BL and Xue AG. Planting date and nitrogen effects on grain yield and protein content of spring wheat. Crop Sciences. 2007; 47:36-44.

Tadesse T, Assefa A, Liben M and Tadesse Z. Effect of nitrogen split application on productivity, nitrogen use efficiency and economics benefits of maize production in Ethiopis. International Journal of Agriculture Policy and Research. 2013; 1(4): 109-115.

Tripathi SC, Chander S and Meena RP. Effect of residue retention, tillage options and timing of nitrogen application in ricewheat cropping system. SAARC Journal of Agriculture.2010; 13: 37-49.

Usman K, Khan EA, Khan N, Khan MA, Ghulam S, Khan S and Baloch. Effect of tillage and nitrogen on wheat production, economics and soil fertility in rice-wheat cropping system. American Journal of Plant Sciences. 2012; 4:17-25.

\section{How to cite this article:}

Navdeep Kaur, Iqbal Singh and Santosh Kumar. 2020. Effect of Tillage and Nitrogen Scheduling on Nutrients Uptake and Economics of Wheat (Triticum aestivum L.) in Central Punjab. Int.J.Curr.Microbiol.App.Sci. 9(08): 2251-2259. doi: https://doi.org/10.20546/ijcmas.2020.908.258 